\title{
Predicting the Cooling Potential of Different Shading Methods for Greenhouses in Arid Regions
}

\author{
Ahmed Abdel-Ghany ${ }^{1,2, *(\mathbb{D}}$, Ibrahim Al-Helal ${ }^{1}$, Fahad Alkoaik ${ }^{1}$, Abdullah Alsadon ${ }^{3}{ }^{-1}$, \\ Mohamed Shady ${ }^{1}$ and Abdullah Ibrahim ${ }^{3}$ \\ 1 Department of Agricultural Engineering, College of Food and Agriculture Sciences, King Saud University, \\ P.O. Box 2460, Riyadh 11451, Saudi Arabia; imhelal@ksu.edu.sa (I.A.-H.); falkoaik@ksu.edu.sa (F.A.); \\ mshady@ksu.edu.sa (M.S.) \\ 2 Department of Mech. Eng., Faculty of Energy Engineering, Aswan University, Aswan 81528, Egypt \\ 3 Department of Plant Production, College of Food and Agriculture Sciences, King Saud University, \\ P.O. Box 2460, Riyadh 11451, Saudi Arabia; alsadon@ksu.edu.sa (A.A.); adrahim@ksu.edu.sa (A.I.) \\ * Correspondence: aghany@ksu.edu.sa; Tel.: +966-541374952
}

Received: 19 November 2019; Accepted: 9 December 2019; Published: 11 December 2019

\begin{abstract}
Shading greenhouses in a hot and sunny climate is essential to reduce the inside greenhouse air temperature. However, the type and location of nets need to be addressed properly to determine the shading method that provides a better cooling effect on the greenhouse air. This study was conducted to evaluate the effects of five different shading methods on greenhouse microclimates, and to investigate the cooling potential of each method. Four greenhouse models covered with 200- $\mu \mathrm{m}$ thick plastic film were used for the study: one was kept as control (C), one was whitened with slaked lime $(\mathrm{L})$, and two were shaded with white and black nets ( $50 \%$ shading factor) deployed simultaneously at two locations, in contact (WC, BC) and at 20-cm distance from the cladding film (WD, BD). The microclimatic parameters were measured inside and outside the greenhouse models, and the cooling potential $(\mathrm{CP})$ was predicted for each shading method. The results showed that the black net at 20-cm distance (BD) is desirable as it provides high $C P$ with a reasonable solar radiation transmission. The maximum $\mathrm{CP}$ was estimated as $8.5^{\circ} \mathrm{C}, 8^{\circ} \mathrm{C}, 6^{\circ} \mathrm{C}, 3.2^{\circ} \mathrm{C}$, and $2.1^{\circ} \mathrm{C}$ for $\mathrm{L}, \mathrm{BD}$, $\mathrm{BC}, \mathrm{WD}$, and $\mathrm{WC}$, respectively. Shading with white nets is not recommended because their cooling potential is very low. Based on these results, we developed correlations for predicting the $C P$ for each shading method as a function of the transmitted solar radiation flux $\left(S_{\mathrm{i}}\right)$. These correlations depend on $S_{\mathrm{i}}$. Accordingly, they can be used for small greenhouses, whitewashed with a slaked lime of any concentration, or shaded with a black net having any shading factor.
\end{abstract}

Keywords: shading nets; solar radiation; heating; cooling; greenhouse; hot regions

\section{Introduction}

In arid regions such as in the Arabian Peninsula, the air temperature exceeds $45^{\circ} \mathrm{C}$ in most of the autumn, summer, and spring months due to the high levels of solar irradiance $\left(900-1100 \mathrm{Wm}^{-2}\right)$ [1]. Besides, due to the harsh climate, water resources are scarce and brackish. This has led to the rapid expansion of the use of greenhouses for crop protection. The critical challenge facing greenhouse operation under these conditions is the unacceptable increases of the inside greenhouse air temperature, which requires appropriate cooling methods to provide a favorable environment for crop growth [1,2]. Preventing solar heat load from entering the greenhouse is the most appropriate method for cooling greenhouses in arid regions [3]. Through this method, solar radiation can be reduced before entering the greenhouse by cutting-off (via absorption or reflection) a portion of the incident radiation on the greenhouse cover [1-3]. This can be accomplished by deploying fixed or movable shading 
nets below or above the roof of the greenhouse [4]. In sunny and hot regions, extensive use of plastic nets for shading greenhouses in summer has been recorded because of their positive impacts on the greenhouse microclimate, the productivity of crops, and many other environmental and economical benefits [1-4]. Plastic nets are also used as standalone covers (net houses) for modifying the microclimate, saving energy and water consumption, and protecting crops against virus-vector insects and birds $[5,6]$. In addition to their use in greenhouses, shading is also used for designing low-energy buildings to enhance solar gains in winter and to reduce overheating in summer. For example, an effective shading structure was developed for a low-energy house to maximize solar gain in winter and eliminate overheating in summer [7]. Net Zero energy retrofit shading strategies were applied to an existing multi-storey residential building to minimize the annual heating and cooling loads, and a shading factor of $0.5-0.7$ was recommended to be effective for minimizing energy consumption [8]. In greenhouse applications, deploying nets or screens below the roof of the greenhouse (internal shading) decreases the effectiveness of natural ventilation and negatively affects the greenhouse microclimate. Moreover, internal nets absorb solar radiation and add thermal emissions that increase the heat load in the greenhouse and the inside air temperature as well. Therefore, external shading is strongly recommended for cooling the greenhouse air [2,3]. A traditional inexpensive shading method is spraying the outer surface of the greenhouse cover with an aqueous solution of hydrated Calcium oxide $\left(\mathrm{Ca}(\mathrm{OH})_{2}\right)$, a process that is called "whitening by slaked lime" [9,10]. Whitening the greenhouse cladding is used for reducing the solar heating load during summer, similar to shading by plastic nets. In general, shading via whitening or deploying plastic nets reduces the greenhouse transmittance to solar radiation. However, under intensive solar irradiance, this is not a serious problem because the transmitted solar radiation can fulfill crop growth requirements [11]. Several studies have measured how whitening the roof of a naturally ventilated greenhouse by slaked lime affects the daily average of the inside air temperature $\left(\bar{T}_{a i}\right)$ and the transmitted solar radiation $\left(S_{\mathrm{i}}\right)$. For example, in [12], whitening reduced $S_{\mathrm{i}}$ by $20 \%$, and in [9] $S_{\mathrm{i}}$ was reduced by $38 \%$ and $\bar{T}_{a i}$ by $5{ }^{\circ} \mathrm{C}$. In [13], whitening reduced $\bar{T}_{a i}$ by $9.38{ }^{\circ} \mathrm{C}$ at around noon, and $\bar{T}_{a i}$ was reduced by $32 \%$ and $S_{i}$ by $41 \%$ in [14]. In [10] whitening reduced $S_{\mathrm{i}}$ by $22 \%$ and $\bar{T}_{a i}$ by $0.8{ }^{\circ} \mathrm{C}$, and in [15] whitening reduced $S_{\mathrm{i}}$ by $30 \%$ and $\bar{T}_{a i}$ by $4{ }^{\circ} \mathrm{C}$. Unlike the whitening effects, the reduction in the transmitted solar radiation and the inside air temperature due to nets or screen shading depends on the type and color of nets, in addition to other meteorological factors. For example, deploying various types of nets, and having different colors and shading factors over naturally ventilated greenhouses reduced the daily average of the inside air temperature $\left(\bar{T}_{a i}\right)$ by $2-6{ }^{\circ} \mathrm{C}$ [16-19] and reduced the transmitted solar radiation by $30-50 \%[18,20,21]$. In arid summer climates (ambient air temperature, $T_{\mathrm{am}}>45^{\circ} \mathrm{C}$ ), shading the naturally ventilated greenhouse is not sufficient to provide an adequate environment for crop growth. Therefore, shading is usually integrated with evaporative cooling. A review of greenhouse shading combined with evaporative cooling concluded that shading with an evaporative cooling system is able to maintain $\bar{T}_{a i}$ at $5-10{ }^{\circ} \mathrm{C}$ lower than $T_{\mathrm{am}}$ and increase the relative humidity by about $15-20 \%$ [3].

In the literature, the reported values of the reduction in the $\bar{T}_{a i}$ and $S_{\mathrm{i}}$ as affected by shading were obtained from in situ experiments conducted on greenhouses worldwide under climatic conditions different from the arid climate. The reported results depended on the in situ meteorological conditions and the radiative properties of the covering and shading materials. However, a general method that can be used to predict the cooling potential of shading is still unclear, and such a methodology is not available in the literature. The cooling potential is defined as the capability of shading to reduce the inside greenhouse air temperature $\left(T_{\text {ai-s }}\right)$ below the air temperature inside an identical, un-shaded (control) greenhouse $\left(T_{\text {ai-c }}\right)$. However, in the un-shaded greenhouse, the air is heated by solar energy transmitted into the greenhouse over the ambient air temperature $\left(T_{\mathrm{am}}\right)$. Then, the heating potential is defined as $\left(T_{\mathrm{ai}-\mathrm{c}}-T_{\mathrm{am}}\right)$. On the other hand, the nominal shading factors of nets provided by the manufacturers are often used to estimate the net shading power. The nominal shading factor does not correctly represent the shading power of the net. Instead, we have developed another definition called "integrated shading factor" of the net [22], which is used in this study. 
Accordingly, this study aimed to evaluate different shading methods for investigating a general procedure to predict the cooling potential of each method. The shading methods were whitening using slaked lime, and external shading using white and black nets, simultaneously deployed in contact and at a $20-\mathrm{cm}$ distance from the greenhouse cladding. This is important since it enables us to determine the optimum location of the shading net to be externally deployed on the greenhouse cladding. This gives the lowest air temperature and the highest cooling potential inside the greenhouse during summer days, thus leading to a reduction of the heating load that needs to be removed via cooling systems in the summer.

\section{Materials and Methods}

\subsection{Experimental Set-Up and Shading Methods}

The experiments were conducted in four identical crop-free, naturally ventilated greenhouse models, each with a floor area of $1.5 \times 2.5 \mathrm{~m}^{2}$, covered with a $200-\mu \mathrm{m}$ thick polyethylene film. A diagrammatic sketch illustrating the outline dimensions of the greenhouse model used in the study is illustrated in Figure 1. The four models were oriented in a north-south direction at the Agricultural Research and Experiment Station, Agriculture Engineering Department, King Saud University (Riyadh, Saudi Arabia, $46^{\circ} 47^{\prime}$ E, longitude and $24^{\circ} 39^{\prime}$ N, latitude). Each greenhouse model was ventilated using 24 holes, of 10-cm in diameter each, made in the cladding film (Figure 1). One greenhouse model was kept without shading (control, C), one was shaded with a slaked lime $(\mathrm{L})\left(\left(\mathrm{Ca}(\mathrm{OH})_{2}\right)-\right.$ water solution, 1:4 by weight), and the other two were shaded using white (W) and black (B) nets deployed simultaneously in two cases: the net at 20-cm distance from the film (WD, BD in Figure 2a), and the net in contact with the cladding film (WC, BC in Figure 2b). The two nets were designated by the supplier as having a $50 \%$ nominal shading factor (white-50 and black-50). Nets with white and black colors were selected for the study to represent the extreme colors of nets, and results of nets having any other colors are expected to fall in between these two colors (white and black).

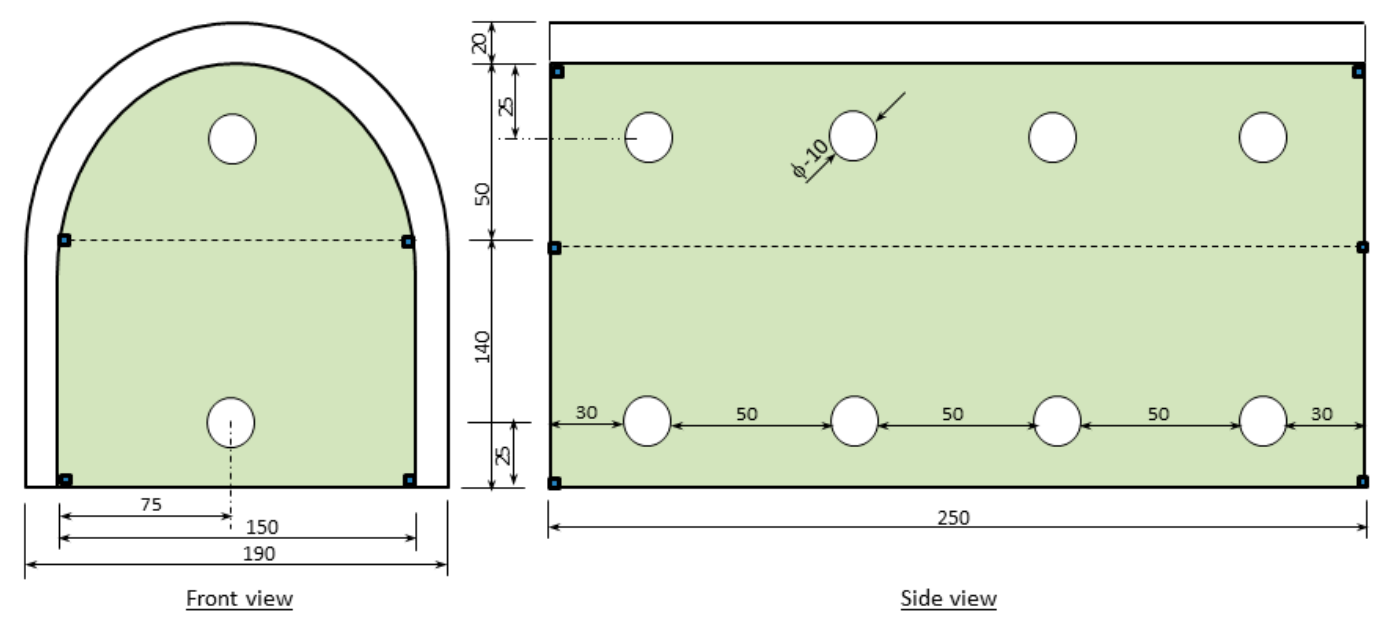

Figure 1. Schematic diagram to illustrate the front and side views of the naturally ventilated greenhouse model used in the study. Dimensions in $\mathrm{cm}$, not to scale. 
(a)
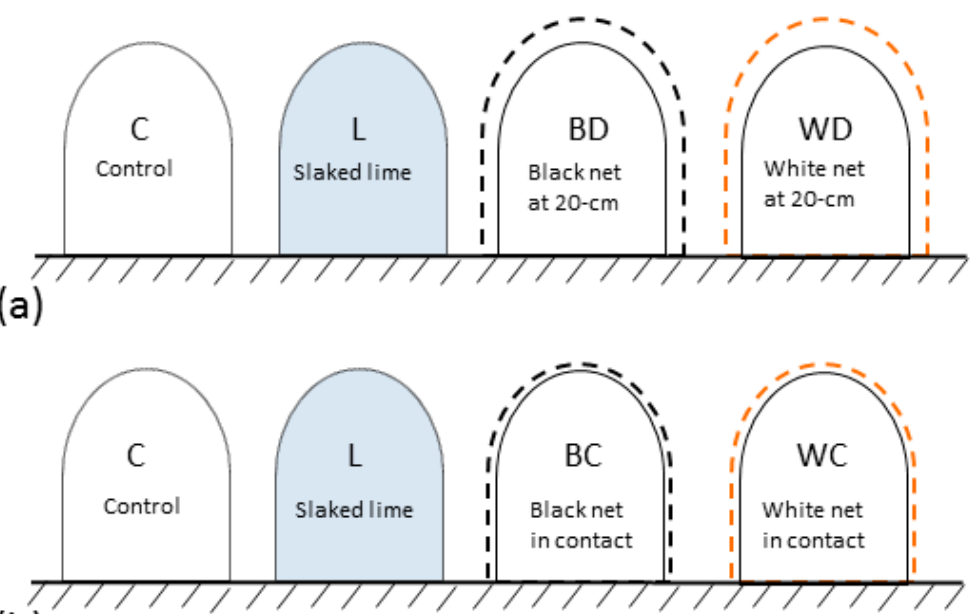

(b)

Figure 2. Schematic diagrams, not to scale, to show the greenhouse models shaded with five shading methods: (a) is for the control (C), slaked lime shading (L), and black and white net deployed at 20-cm distance (BD, WD, respectively), and (b) is for the control (C), slaked lime shading (L), and black and white net deployed in contact with the cladding film (BC, WC, respectively).

\subsection{Measuring the Required Parameters}

The experiments were conducted in the period from 30 October to 7 November 2018. Two days for the two shading methods were selected for the study: October 31 was for the control (C), whitened with slaked lime (L), shaded with white net at $20 \mathrm{~cm}$ distance (WD), and shaded with black net at $20-\mathrm{cm}$ distance (BD), as in Figure 2a. November 6 was for the control (C), whitened with slaked lime (L), shaded with a white net in contact with the film cover (WC), and shaded with black in contact with the film cover (BC), as illustrated in Figure 2b. The measured parameters were: (i) The downward global solar radiation flux outside $\left(S_{\mathrm{o}}\right)$, at $2.5 \mathrm{~m}$ height above the floor, and inside $\left(S_{\mathrm{i}}\right)$, at the center of each greenhouse model, using five CMP3 pyranometers (Kipp and Zonen B.V. Inc., USA), each of them having a time response of $18 \mathrm{~s}$, a maximum error of $\pm 2 \%$, a sensitivity of $5-20 \mu \mathrm{VWm}^{-2}$, a working temperature range of -40 to $+80{ }^{\circ} \mathrm{C}$, and a wavelength range of $310-2800 \mathrm{~nm}$. (ii) The air temperature and relative humidity inside (at the center of each greenhouse model) and outside (at $2.5 \mathrm{~m}$ height above the floor) using DMA033 Thermo-hygrometers (LSI-Lastem, Milano, Italy). The sensors were calibrated before use by the supplier. These parameters were measured every $1 \mathrm{~min}$, averaged at every $10 \mathrm{~min}$, and recorded in a data logger (CR23X Micro logger, Campbell Scientific, Inc.).

Before starting the experiments, the spectral radiative properties (transmittance and reflectance in solar spectrum wavebands) of the tested nets and plastic film were measured in the laboratory at normal incidence using a Black-Comet spectrophotometer (StellarNet Inc., USA), scanning between $200 \mathrm{~nm}$ and $1700 \mathrm{~nm}$ at $0.5 \mathrm{~nm}$ intervals in the UV-VIS-NIR range. The measured data were averaged at each $20 \mathrm{~nm}$ interval and depicted in Figure 3a-c. The total radiative property (over the whole wavelength range) to global solar radiation, of a cladding film and/or a shading net, was estimated as the weighted average value of the spectral properties. The weighting function is the spectral distribution of solar irradiance measured at the ground level $\left(S_{\lambda}\right.$ in $\left.\mathrm{W} \mathrm{m}^{-2} \mathrm{~nm}\right)$. Then, the total property is given according to $[23,24]$ as follows:

$$
P=\frac{\int_{\lambda=200}^{\lambda=2500} P_{\lambda} S_{\lambda} d \lambda}{\int_{\lambda=200}^{\lambda=2500} S_{\lambda} d \lambda}
$$

where $P$ and $P_{\lambda}$ are the total and spectral properties of the plastic film or net. The numerical integration was carried out by using the trapezoid rule. Owing to the capacity of the available spectrophotometer, the upper limit of $\lambda$ in Equation (1) was taken as $1700 \mathrm{~nm}$ instead of $2500 \mathrm{~nm}$. This assumption does not affect the accuracy of the analysis because the remaining part of solar irradiance $\left(S_{\lambda}\right)$, from $1700 \mathrm{~nm}$ 
to $2500 \mathrm{~nm}$, is minor and can be neglected [25]. The integrated shading factor (ISF) of the net was estimated according to [22] as follows:

$$
I S F=1-\frac{\int_{t 1}^{t 2} S_{i}(t) d t}{\int_{t 1}^{t 2} S_{o}(t) d t}
$$

where $S_{\mathrm{o}}$ and $S_{\mathrm{i}}$ are the solar radiation flux incident over and transmitted below the net, and $t_{1}$ and $t_{2}$ are the sunrise and sunset times. The cooling potential $(C P)$ of shading, at a certain time of the day, was estimated as $C P=\left(T_{\text {ai-c }}-T_{\text {ai-s }}\right)$, where $T_{\text {ai-c }}$ and $T_{\text {ai-s }}$ are the air temperatures inside the un-shaded (control) and shaded greenhouse, respectively. However, air in the un-shaded greenhouse is heated by solar radiation incident over, and transmitted into the greenhouse, and the heating potential $(H P)$ was estimated as $\left(T_{\mathrm{ai}-\mathrm{c}}-T_{\mathrm{am}}\right)$, where $T_{\mathrm{am}}$ is the ambient air temperature.

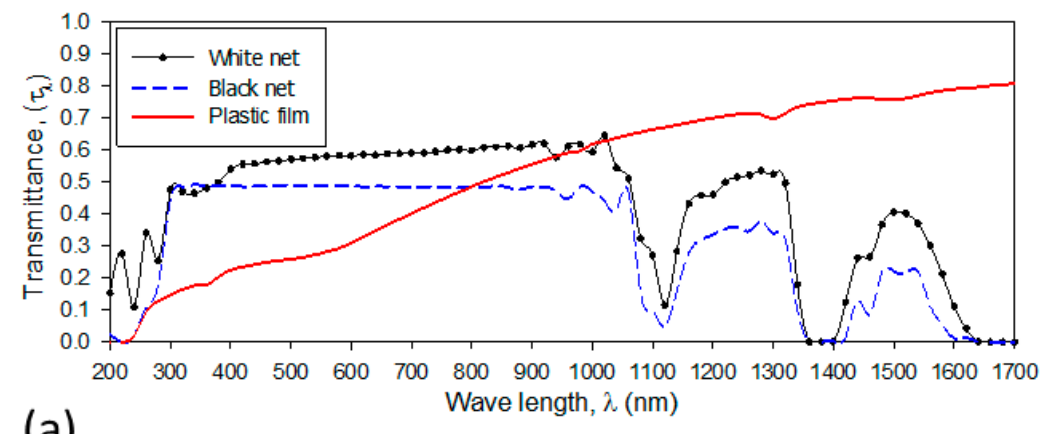

(a)
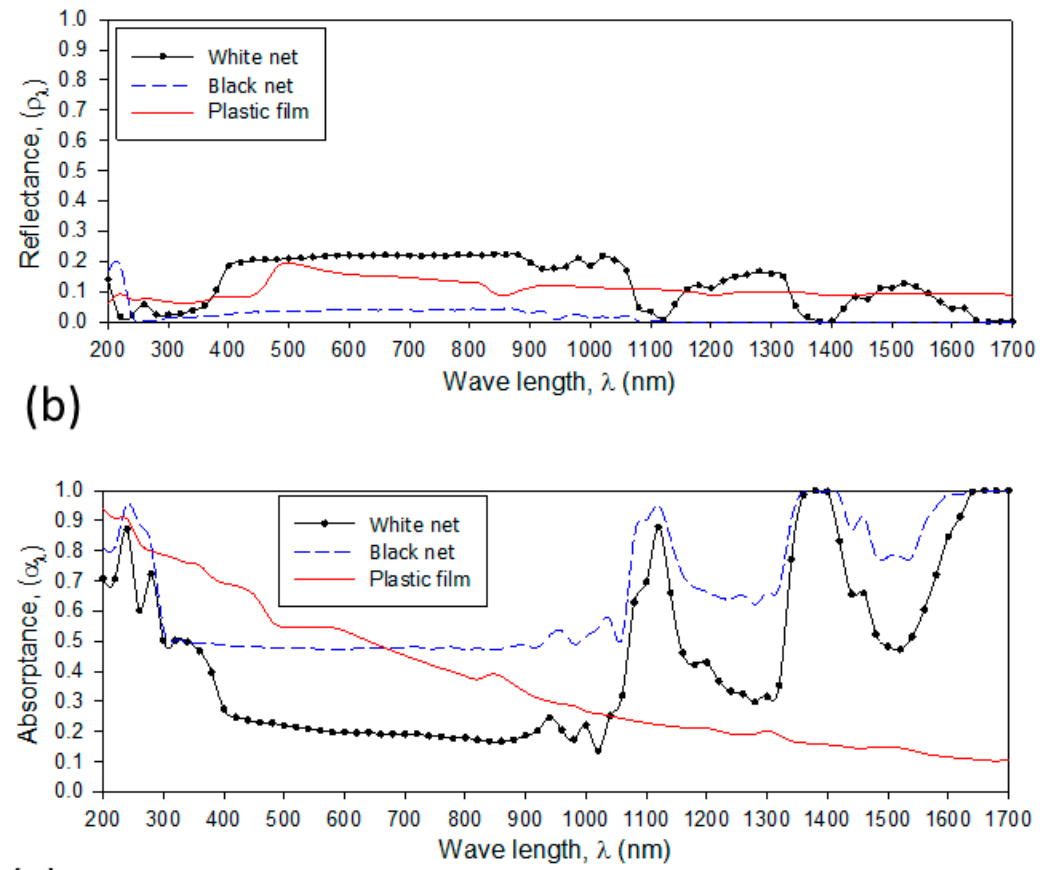

(c)

Figure 3. Spectral radiative properties, measured in the laboratory, for the white net, black net, and plastic film used for the study: (a) transmittance, (b) reflectance, and (c) absorptance.

\section{Results and Discussion}

The results of the spectral radiative properties over the solar spectrum waveband for the tested materials (plastic film, white net, and black net) were measured and are illustrated in Figure 3a-c. Figure 3 a shows spectral transmittance $\left(\tau_{\lambda}\right)$, Figure 3 b shows reflectance $\left(\rho_{\lambda}\right)$, and Figure $3 c$ shows 
absorptance $\left(\alpha_{\lambda}\right)$. For the overall evaluation, the spectral properties shown in Figure 3a-c were integrated by using Equation (1) to estimate the total radiative properties over the whole wavelength range (200-1700 nm), as depicted in Table 1 . The daily integral of the radiative properties to global solar radiation (200-2500 nm) and the integrated shading factor (ISF) of the tested nets were estimated in our previous study, by using Equation (2), based on outdoor experimental measurements conducted with these materials [22], and the results are reported in Table 1. The reported results showed that the ISF of the black net was higher than that of the white net. For each material, the daily integral of the transmittance and reflectance measured under natural outdoor solar radiation conditions were higher than the total transmittance and reflectance measured in the laboratory. This may be attributed to: (i) measurements in the laboratory used a spectrophotometer, in which the radiation source was a direct beam only, (ii) measurements in the outdoors were under global solar radiation, in which diffuse radiation was predominant in the morning and afternoon, and (iii) the average transmittance of a translucent material to diffuse radiation is usually higher than that of direct beam radiation.

Table 1. Results of the total and integrated radiative properties, and the integrated shading factor (ISF) of the experimental materials to global solar radiation.

\begin{tabular}{cccccccc}
\hline \multirow{2}{*}{ Material } & \multirow{2}{*}{ ISF (-) } & \multicolumn{2}{c}{ Transmittance (-) } & \multicolumn{2}{c}{ Reflectance (-) } & \multicolumn{2}{c}{ Absorptance (-) } \\
\cline { 3 - 8 } & & Total & Integrated & Total & Integrated & Total & Integrated \\
\hline Black-50 net & 0.54 & 0.45 & 0.46 & 0.03 & 0.08 & 0.52 & 0.46 \\
White-50 net & 0.38 & 0.55 & 0.62 & 0.19 & 0.37 & 0.26 & 0.01 \\
Plastic film & - & 0.65 & 0.50 & 0.12 & 0.22 & 0.23 & 0.28 \\
\hline
\end{tabular}

To conduct an experiment as in Figure 2a,b simultaneously, 27 devices are required to measure the air temperature, relative humidity, and solar radiation flux (nine for each parameter). Therefore, the experiment was conducted on two days (31 October and 6 November 2018), one day for each case (Figure 2a,b). The diurnal variations of solar radiation transmitted into the greenhouse models in the two cases (i.e., nets were at $20-\mathrm{cm}$ distance and were in contact with the cladding film) are illustrated in Figure 4a,b, respectively. In general, shading by slaked lime (L), nets at 20-cm distance (WD, BD), or nets in contact with the film (WC, BC) reduced the transmitted solar radiation into the greenhouse to levels below those of the un-shaded greenhouse (C). The reduction was according to the total transmittance value of each shading material to global solar radiation (Table 1). In addition, the white net, either at 20-cm distance (WD) or in contact (WC), transmitted solar radiation much more than the black net and slaked lime (BD, BC, and L). For the overall evaluation, the daily integral of the greenhouse transmittance in each case was estimated by using the results in Figure $4 \mathrm{a}, \mathrm{b}$, as illustrated in Table 2. Slaked lime shading showed the lowest transmittance due to the high concentration of $\left(\mathrm{Ca}(\mathrm{OH})_{2}\right)$ in the whitening solution. The white net shading showed a higher transmittance than black net shading. The greenhouse model shaded with nets deployed at $20-\mathrm{cm}$ distance showed a lower transmittance than those shaded with nets deployed in contact with the cladding film (Table 2). This is because the multiple reflections of solar radiation in the gap between the net and the cladding film enhanced the backward reflection and reduced solar radiation before entering the greenhouse. This result confirms that shading materials should be deployed outside and apart from the greenhouse cladding in order to fully realize their potential for shading and reduce the transmitted solar radiation. 


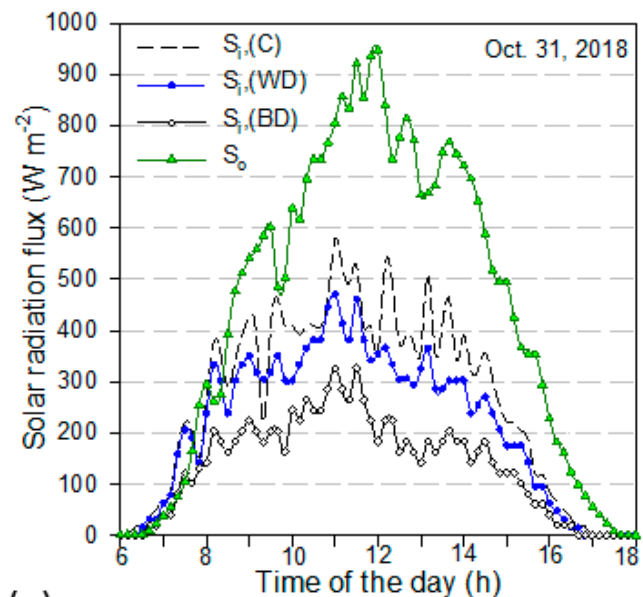

(a)

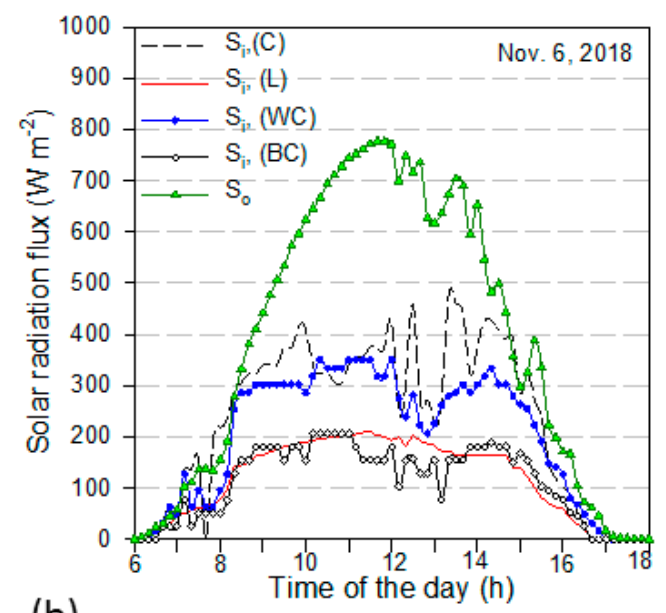

(b)

Figure 4. Diurnal variation of the outside $\left(S_{\mathrm{o}}\right)$ and inside $\left(S_{i}\right)$ solar radiation flux incident and transmitted into the greenhouse models; (a) is for the configuration in Figure $2 \mathrm{a}$ and $(\mathbf{b})$ is for the configuration in Figure 2b.

Table 2. Results of the daily integral of the greenhouse models transmittances to global solar radiation: $\mathrm{C}$ is control, $\mathrm{L}$ is shaded with slaked lime, (WD, BD) are shaded with white and black nets, respectively, at 20-cm distance, and (WC, BC) are shaded with white and black nets, respectively, in contact with the film cover.

\begin{tabular}{cccc}
\hline \multicolumn{2}{c}{ Shading Methods, Figure 2a } & \multicolumn{2}{c}{ Shading Methods, Figure 2b } \\
\hline Greenhouse Model & Integrated Transmittance (-) & Greenhouse Model & Integrated Transmittance (-) \\
\hline C & 0.63 & C & 0.63 \\
L & 0.26 & L & 0.26 \\
WD & 0.44 & WC & 0.51 \\
BD & 0.29 & BC & 0.49 \\
\hline
\end{tabular}

During the daytime in summer, shading moderates the transmitted solar radiation as well as the air temperature in the greenhouses. However, shading location affects the generated thermal radiation in the greenhouse due to the net thermal emissions [2]. A net in contact with the cladding film increases the film temperature and its thermal emission as well. In the naturally ventilated greenhouse, the inside greenhouse air temperature $\left(T_{\mathrm{ai}}\right)$ depends mainly on the outside ambient temperature $\left(T_{\mathrm{am}}\right)$, transmitted solar radiation $\left(S_{\mathrm{i}}\right)$, and the type and location of shading nets. Since the measurements were conducted on two different days having different levels of ambient temperatures (Figure 5a,b) and different levels of solar radiation flux (Figure $4 a, b$ ), the temperature difference, therefore, of air between the inside and outside of the greenhouse models $\left(T_{\mathrm{ai}}-T_{\mathrm{am}}\right)$ was used to show the effect of the shading method on the decreases in $T_{\mathrm{ai}}$. The radiation levels $\left(S_{\mathrm{o}}\right.$ and $\left.S_{\mathrm{i}}\right)$ on October 31 (Figure 4a) were higher than those on November 6 (Figure $4 \mathrm{~b}$ ). However, $T_{\text {am }}$ was higher on November 6 (Figure $5 b$ ) than $T_{\mathrm{am}}$ on October 31 (Figure $5 \mathrm{a}$ ). Therefore, the levels of temperature difference $\left(T_{\mathrm{ai}}-T_{\mathrm{am}}\right)$ for every shading method and un-shaded (control) greenhouse model shown in Figure 5a were higher than those shown in Figure $5 \mathrm{~b}$. The low value of $\left(T_{\mathrm{ai}}-T_{\mathrm{am}}\right)$ means the shading method effectively reduced the inside greenhouse air temperature $\left(T_{\mathrm{ai}}\right)$. As seen in Figure $5 \mathrm{~b}$, slaked lime shading showed the lowest inside air temperature rise $\left(T_{\mathrm{ai}}-T_{\mathrm{am}}\right)$, followed by the black net (Figure $\left.5 \mathrm{a}, \mathrm{b}\right)$. This depended on the transmittance values shown in Table 2. However, the white net either deployed at 20-cm distance or in contact with the cladding film did not significantly reduce $T_{\mathrm{ai}}$ below the $T_{\mathrm{ai}}$ of the un-shaded (control) greenhouse model (Figure 5a,b). Once more, even though the nominal shading factor of the two nets was the same $(50 \%)$, the black net showed a higher shading effect than the white net because 
the white color increased the forward scattering of the solar beam and consequently enhanced the transmitted solar radiation into the greenhouse models.

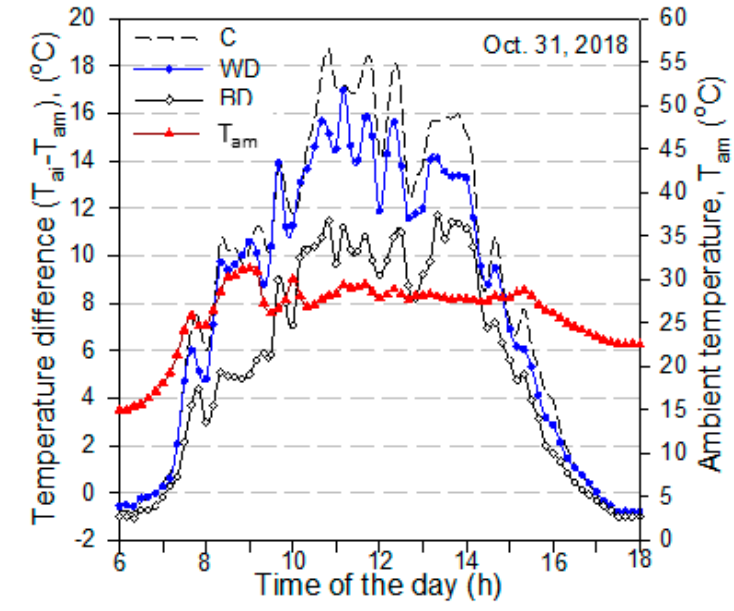

(a)

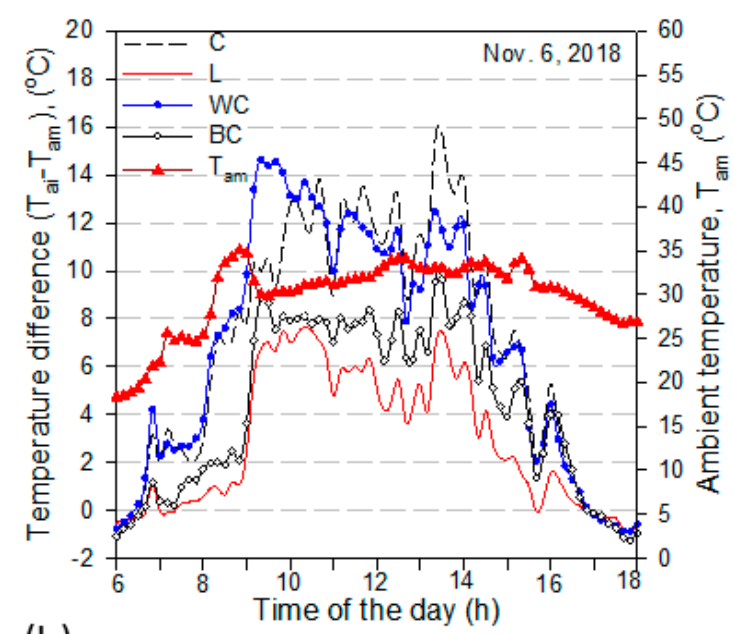

(b)

Figure 5. Diurnal variation of the air temperature difference between inside and outside the greenhouse models $\left(T_{\mathrm{ai}}-T_{\mathrm{am}}\right)$ and the ambient temperature $\left(T_{\mathrm{am}}\right)$; $(\mathbf{a})$ is for the configuration in Figure $2 \mathrm{a}$ and $(\mathbf{b})$ is for the configuration in Figure $2 b$.

The transmitted solar radiation $\left(S_{\mathrm{i}}\right)$ is the main source of energy in the greenhouse. $S_{\mathrm{i}}$ is absorbed by the greenhouse components (plants, soil, cover, internal structure, etc.). However, the greenhouse air does not absorb solar or thermal radiation directly. The absorbed solar radiation is released as: (i) sensible heat contributing to the increases in greenhouse air temperature, (ii) latent heat in the form of evapo-transpiration, and (iii) thermal radiation exchange among the greenhouse solid components [26]. The contribution of thermal radiation to the total energy in the greenhouse is low, it was estimated to be $5.8 \%$ in the un-shaded greenhouse and $9 \%$ in the externally shaded greenhouse in the summer [2]. As a result, more than $70 \%$ of the transmitted solar radiation $\left(S_{\mathrm{i}}\right)$ is transformed to sensible heat used to increase the air temperature [26]. Therefore, correlating the heating and cooling potentials ( $H P$ and $C P$ ) as functions of $S_{i}$ is desirable, since there is no other energy source, except $S_{i}$, that can significantly affect the inside air temperature. During the day time in winter seasons, the greenhouse is used without shading (as the control, C, in this study) for warming up the inside air for plant growth, and deploying shading nets at night is desirable to provide a warming effect on the greenhouse air by reducing the thermal loss from the greenhouse to the outside. For the control greenhouse model $(C)$, the heating effect is expressed by $\left(T_{\text {ai-c }}-T_{\text {am }}\right)$, where $T_{\text {ai-c }}$ is the air temperature inside the greenhouse. To predict the heating potential of the greenhouse (that is mainly induced by $\left.S_{i}\right)$, values of $\left(T_{\text {ai-c }}-T_{\mathrm{am}}\right)$ were plotted against the corresponding values of $S_{\mathrm{i}}$ in Figure 6a. Based on the data in Figure $6 \mathrm{a}$, the heating potential $(H P)$, in ${ }^{\circ} \mathrm{C}$, could be correlated $\left(R^{2}=0.88\right)$ as a linear function of $S_{\mathrm{i}}\left(\mathrm{W} \mathrm{m} \mathrm{m}^{-2}\right)$ in the following form:

$$
H P=-0.15+0.033 S_{i}
$$




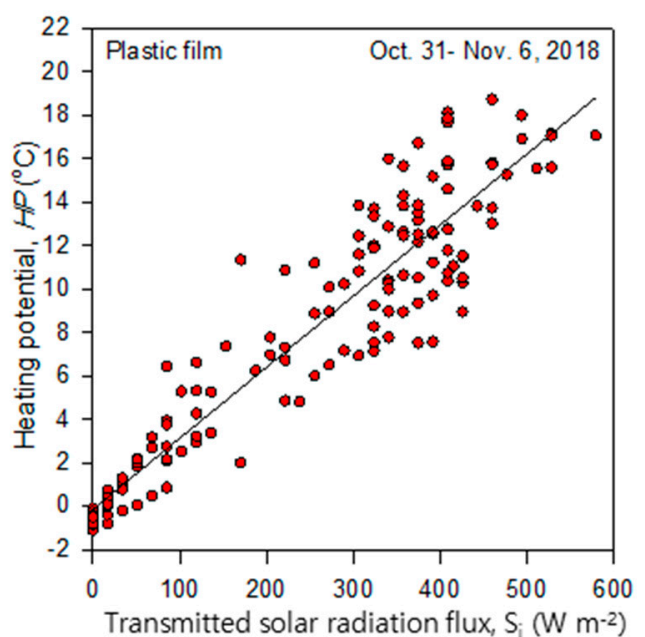

(a)

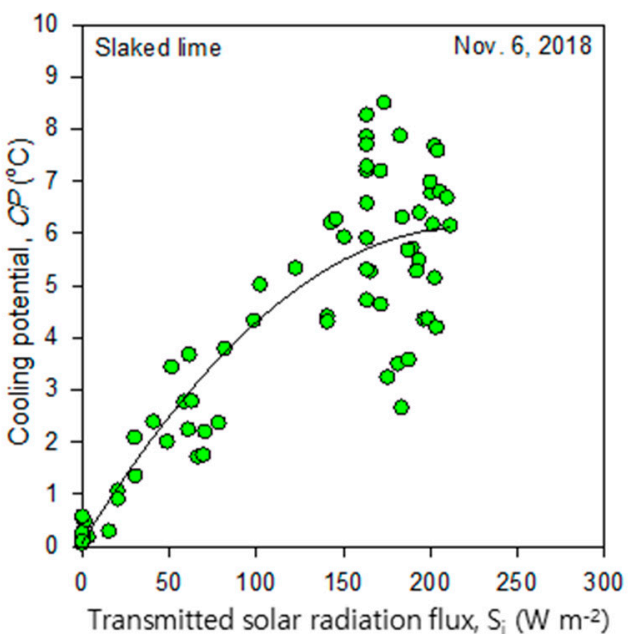

(b)

Figure 6. (a) The heating potential (HP) as affected by the transmitted solar radiation $\left(S_{\mathrm{i}}\right)$ into the un-shaded (control) greenhouse model, and (b) the cooling potential (CP) of slaked lime shading as affected by $S_{\mathrm{i}}$.

According to Equation (3), in a naturally ventilated small greenhouse covered with a plastic film (200- $\mu \mathrm{m}$ thick), a transmitted solar radiation higher than $50\left(\mathrm{~W} \mathrm{~m}^{-2}\right)$ would have a warming effect on the greenhouse air. This experiment was conducted with a greenhouse model having an air volume to floor surface area ratio $\left(V_{\mathrm{a}} / A_{\mathrm{f}}\right)$ of $1.7 \mathrm{~m}$. However, the $H P$ is expected to decrease with increases of the $V_{\mathrm{a}} / A_{\mathrm{f}}$ for large-scale and commercial greenhouses. On the other hand, shading reduces the inside greenhouse air temperature $\left(T_{\text {ai-s }}\right)$ below air temperature in the un-shaded (control) greenhouse $\left(T_{\text {ai-c }}\right)$, and the cooling potential of shading is estimated as $\left(T_{\text {ai-c }}-T_{\text {ai-s }}\right)$. Slaked lime shading showed a high cooling effect due to the low transmitted radiation. Values of $\left(T_{\text {ai-c }}-T_{\text {ai-s }}\right)$ were plotted against $S_{\mathrm{i}}$ in Figure $6 \mathrm{~b}$, and then a correlation $\left(R^{2}=0.8\right)$ to express the cooling potential $(C P)$ in ${ }^{\circ} \mathrm{C}$ for a slaked lime shading (Calcium hydroxide, 1:4 by weight) was obtained in the following form:

$$
C P=0.07+0.055 S_{i}-0.0001 S_{i}^{2}
$$

In Figure $6 \mathrm{~b}$, the highest cooling potential $(\mathrm{CP})$ of $8-8.5^{\circ} \mathrm{C}$ was recorded when the transmitted radiation $S_{\mathrm{i}}$ was between 150 and $200\left(\mathrm{~W} \mathrm{~m}^{-2}\right)$, whereas for $S_{\mathrm{i}}>200\left(\mathrm{~W} \mathrm{~m}^{-2}\right)$ the $C P$ may not improve significantly according to Equation (4) and the fitting curve in Figure $6 \mathrm{~b}$. The reason for this may be attributed to the fact that the high $S_{\mathrm{i}}$ level in the greenhouse corresponds with a heating load higher than the shading capacity. Similarly, values of $\left(T_{\text {ai-c }}-T_{\text {ai-s }}\right)$ were plotted against $S_{\mathrm{i}}$ in Figure $7 \mathrm{a}, \mathrm{b}$ for the black net shading deployed at $20-\mathrm{cm}$ distance $(\mathrm{BD})$ and in contact with the cladding film $(\mathrm{BC})$, respectively. Two correlations could be obtained to express the cooling potential $(\mathrm{CP})$ of each case:

Black net at 20-cm distance (Figure 7a):

$$
C P=0.225+0.026 S_{i}-1.54 \times 10^{-5} S_{i}^{2},\left(R^{2}=0.83\right) .
$$

Black net in contact with the film (Figure 7b):

$$
C P=0.133+0.034 S_{i}-7.3 \times 10^{-5} S_{i}^{2},\left(R^{2}=0.75\right) .
$$




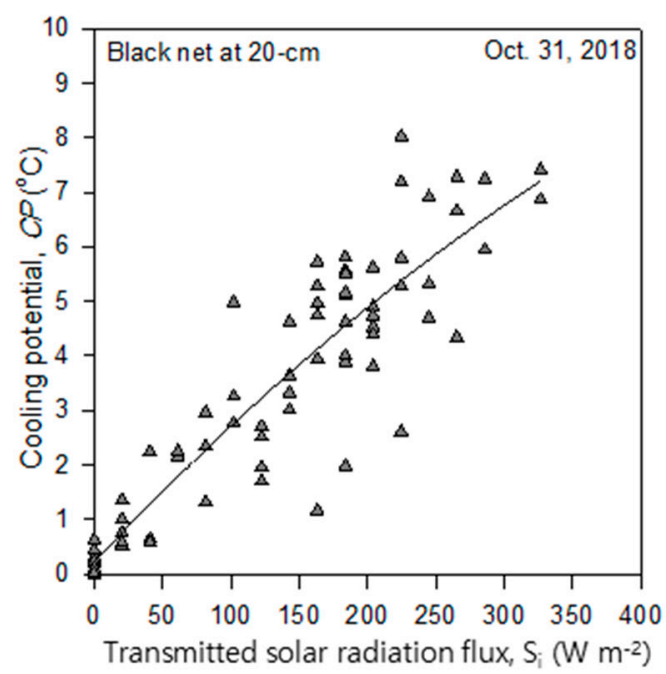

(a)

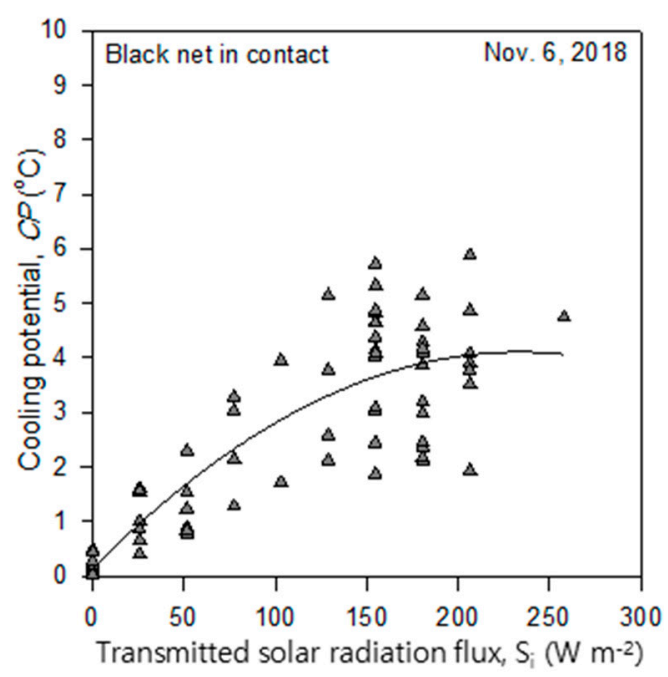

(b)

Figure 7. The cooling potential (CP) of the black net shading as affected by the transmitted solar radiation $\left(S_{\mathrm{i}}\right)$ into the greenhouse model: (a) the net was deployed at 20-cm distance (BD), and (b) the net was deployed in contact with the cladding film (BC).

The black net deployed at 20-cm distance from the cladding film (BD) showed higher $C P$ (up to $8^{\circ} \mathrm{C}$ ) and higher $S_{\mathrm{i}}$ (up to $350 \mathrm{~W} \mathrm{~m}^{-2}$ ) than those for the black net deployed in contact with the film (BC), where the $C P$ was up to $6{ }^{\circ} \mathrm{C}$ and $S_{\mathrm{i}}$ was up to $250\left(\mathrm{~W} \mathrm{~m}^{-2}\right)$ (Figure $\left.7 \mathrm{a}, \mathrm{b}\right)$. In Figure 7 a the $C P$ proportionally increased with increasing $S_{\mathrm{i}}$. However, in Figure $7 \mathrm{~b}$, the $\mathrm{CP}$ tended to be constant with increasing $S_{\mathrm{i}}$ because the black net in contact with the cladding film increased the film temperature as well as the thermal load in the greenhouse, consequently reducing the shading effect of the net. For the white net, which deployed at 20-cm distance and in contact with the film, values of $\left(T_{\text {ai-c }}-T_{\text {ai-s }}\right)$ were plotted against $S_{\mathrm{i}}$ in Figure 8a,b, respectively. The white net shading (WD, Figure 8a, and WC, Figure $8 \mathbf{b}$ ) showed the lowest $\mathrm{CP}$ values and highest $S_{\mathrm{i}}$ values compared to the other shading methods (L, BD, and $\mathrm{BC}$ ). The $\mathrm{CP}$ values reached to $3.5^{\circ} \mathrm{C}$ and $S_{\mathrm{i}}$ to $480\left(\mathrm{~W} \mathrm{~m}^{-2}\right)$ (Figure $\left.8 \mathrm{a}\right)$, while $C P$ reached to $2.2{ }^{\circ} \mathrm{C}$ and $S_{\mathrm{i}}$ to $380\left(\mathrm{~W} \mathrm{~m}^{-2}\right)$ (Figure $8 \mathrm{~b}$ ). For the white net shading, the resulting low cooling potential $(C P)$ was associated with low correlation coefficients. An attempt was made to express the value of $C P$ as a function of $S_{\mathrm{i}}$ for the white net (data in Figure 8a,b). The resulting $R^{2}$ values were 0.38 and 0.25 , respectively. These correlations cannot be used to predict the cooling potential of the white net shading. In the five shading methods, the maximum cooling potential $\left(C P_{\max }\right)$ occurred at an $S_{\mathrm{i}}$ lower than its maximum value $\left(S_{\mathrm{i}-\mathrm{max}}\right)$. The $\mathrm{CP}$ increased with increasing $S_{\mathrm{i}}$ to a certain limit, but after that, increasing $S_{\mathrm{i}}$ depressed the shading effectiveness as well as the CP. For every shading method, the value of $C P_{\max }$ with the corresponding value of $S_{\mathrm{i}}$, and the value of $\mathrm{CP}$ at $S_{\mathrm{i} \text {-max }}$ are summarized in Table 3. Equations (4)-(6) were derived for small greenhouses. However, the effect of shading on reducing the inside greenhouse air temperature is expected to increase with increasing values of $V_{\mathrm{a}} / A_{\mathrm{f}}$ for large-scale and commercial greenhouses.

Table 3. The maximum cooling potential $\left(C P_{\max }\right)$ and the corresponding solar radiation flux transmitted into the greenhouse model $\left(S_{\mathrm{i}}\right)$; and the cooling potential at $S_{\mathrm{i}-\max }\left(C P_{\mathrm{s}-\mathrm{max}}\right)$ for the five shading methods.

\begin{tabular}{ccccc}
\hline Shading Method & $\boldsymbol{C P}_{\max }\left({ }^{\circ} \mathbf{C}\right)$ & $\boldsymbol{S}_{\mathbf{i}}\left(\mathbf{W} \mathbf{~ m}^{-\mathbf{2}}\right)$ & $\boldsymbol{C P}_{\text {s-max }}\left({ }^{\circ} \mathbf{C}\right)$ & $\boldsymbol{S}_{\text {i-max }}\left(\mathbf{W} \cdot \mathbf{m}^{-\mathbf{2}}\right)$ \\
\hline L & 8.5 & 170 & 6.1 & 211 \\
BD & 8 & 230 & 7.3 & 326 \\
BC & 6 & 210 & 4.5 & 257 \\
WD & 3.2 & 430 & 2.5 & 470 \\
WC & 2.1 & 375 & 1.4 & 382 \\
\hline
\end{tabular}




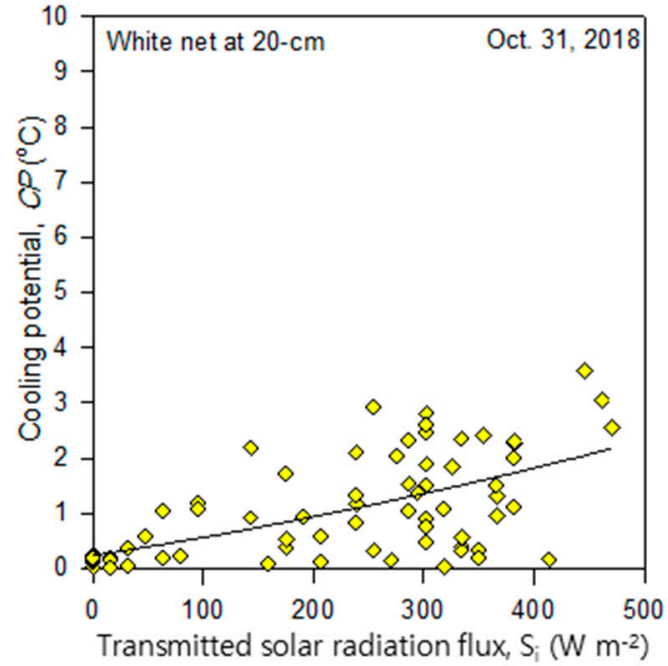

(a)

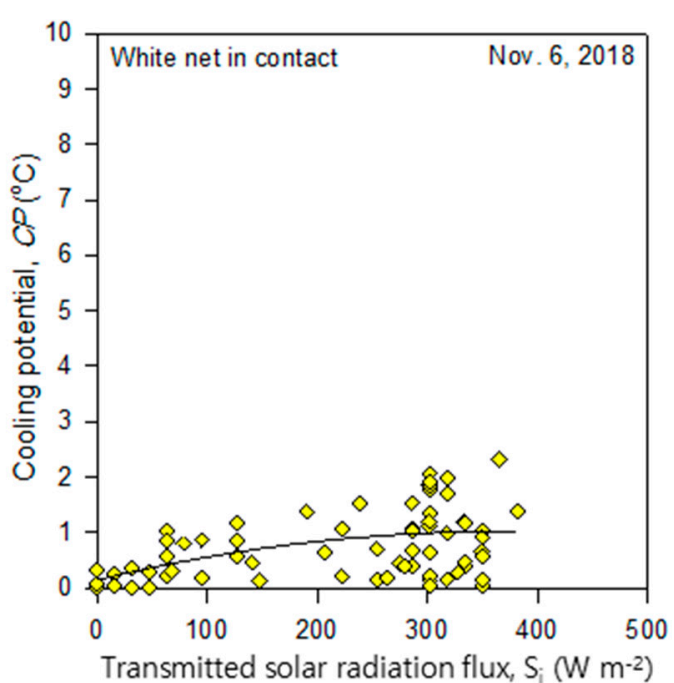

(b)

Figure 8. The cooling potential $(C P)$ of the white net shading as affected by the transmitted solar radiation $\left(S_{\mathrm{i}}\right)$ into the greenhouse model: (a) the net was deployed at 20-cm distance (WD), and (b) the net was deployed in contact with the cladding film (WC).

\section{Conclusions and Recommendations}

Even though plastic nets are extensively used in arid regions for shading greenhouses in summer, nets are often employed as greenhouse elements without any engineering design. This study was conducted to provide a method to predict the cooling potential of five shading methods in terms of their ability to reduce the inside greenhouse air temperature. Therefore, small greenhouse models were used. The shading methods were slaked lime, and black and white nets, each deployed separately in contact and at $20-\mathrm{cm}$ distance from the greenhouse cladding. The white and black nets were selected to represent the extreme colors of nets. The main conclusions can be summarized as follows:

- $\quad$ The black net showed higher cooling potential than the white net. Therefore, nets with dark colors are recommended for shading greenhouses in sunny and hot regions, and external shading at a certain distance from the cladding film is the most desirable method.

- With external shading, the shading power and the required solar radiation in the greenhouse can be controlled by selecting a net with the desired shading factor.

- Slaked lime shading is effective, but its shading effectiveness depends on the density of the whitening solution.

- A black net deployed at $20-\mathrm{cm}$ distance is the best shading method. It provides a high cooling potential with an appropriate solar radiation transmission. However, white nets are not recommended because their cooling potential is very low.

- Three correlations were developed to predict the cooling potential of the slaked lime shading, and black net deployed at 20-cm distance and in contact with the cladding film. These correlations depend on $S_{i}$. Therefore, they can be used for small greenhouses whitewashed with a slaked lime at any concentration and a black net having any shading factors.

- In this study, the $20-\mathrm{cm}$ distance was selected randomly. Therefore, several experiments with solar radiation analysis are required to optimize the distance between the net and the greenhouse cladding.

- More experiential studies are needed to predict the cooling potential of large-scale greenhouses shaded with nets having different dark colors (greens, blues, reds, etc.). 
Author Contributions: A.A.-G. was responsible for the overall coordination of the research team. I.A.-H. prepared and presented the results; A.A. and A.I. did the literature review; M.S. conducted the experiment and collected data. F.A. measured the radiative properties of the materials and conducted the experiments. All the authors were involved in writing and discussing the results, and have read as well as approved the manuscript.

Funding: The authors would like to extend their sincere appreciation to the Deanship of Scientific Research at King Saud University for its funding of this research through the research group no. RG-1435-074.

Conflicts of Interest: The authors declare no conflict of interest.

\section{Nomenclature}

\begin{tabular}{|c|c|}
\hline B & black net \\
\hline $\mathrm{BC}$ & black net in contact with the cladding film \\
\hline $\mathrm{BD}$ & black net at $20-\mathrm{cm}$ distance from the cladding film \\
\hline $\mathrm{C}$ & un-shaded greenhouse model (control) \\
\hline $\mathrm{CP}$ & cooling potential of shading method $\left({ }^{\circ} \mathrm{C}\right)$ \\
\hline$C P_{\max }$ & the maximum cooling potential of shading $\left({ }^{\circ} \mathrm{C}\right)$ \\
\hline$C P_{\text {s-max }}$ & cooling potential at maximum solar radiation transmission $\left({ }^{\circ} \mathrm{C}\right)$ \\
\hline $\mathrm{HP}$ & heating potential of the un-shaded (control) greenhouse model $\left({ }^{\circ} \mathrm{C}\right)$ \\
\hline ISF & integrated shading factor of the net (daily integral) (-) \\
\hline $\mathrm{L}$ & greenhouse model shaded with slaked lime \\
\hline$S_{\mathrm{i}}$ & solar radiation flux transmitted into the greenhouse model $\left(\mathrm{W} \mathrm{m}^{-2}\right)$ \\
\hline$S_{\mathrm{i}, \max }$ & maximum solar radiation flux transmitted into the greenhouse model $\left(\mathrm{W} \mathrm{m}^{-2}\right)$ \\
\hline$S_{\mathrm{o}}$ & solar radiation flux outside the greenhouse model $\left(\mathrm{W} \mathrm{m}^{-2}\right)$ \\
\hline$S_{\lambda}$ & spectral solar radiation flux outside the greenhouse model $\left(\mathrm{W} \mathrm{m} \mathrm{mm}^{-1}\right)$ \\
\hline $\mathrm{t}$ & time $(\mathrm{h})$ \\
\hline$T_{\mathrm{ai}}$ & inside greenhouse air temperature $\left({ }^{\circ} \mathrm{C}\right)$ \\
\hline $\bar{T}_{a i}$ & daily average of the inside greenhouse air temperature $\left({ }^{\circ} \mathrm{C}\right)$ \\
\hline$T_{\text {ai-c }}$ & inside air temperature of the un-shaded greenhouse model (control) $\left({ }^{\circ} \mathrm{C}\right)$ \\
\hline$T_{\mathrm{am}}$ & ambient air temperature $\left({ }^{\circ} \mathrm{C}\right)$ \\
\hline$T_{\text {ai-s }}$ & inside air temperature of the shaded greenhouse model $\left({ }^{\circ} \mathrm{C}\right)$ \\
\hline$V_{\mathrm{a}} / A_{\mathrm{f}}$ & greenhouse air volume per unit area of floor $(\mathrm{m})$ \\
\hline $\mathrm{W}$ & white net \\
\hline WC & white net in contact with the cladding film \\
\hline WD & white net at $20-\mathrm{cm}$ distance from the cladding film \\
\hline$\lambda$ & wave length $(\mathrm{nm})$ \\
\hline$\alpha_{\lambda}$ & spectral absorptance (-) \\
\hline$\rho_{\lambda}$ & spectral reflectance (-) \\
\hline$\tau_{\lambda}$ & spectral transmittance (-) \\
\hline
\end{tabular}

\section{References}

1. Abdel-Ghany, A.M.; Al-Helal, I.M.; El-zahrani, S.M.; Alsadon, A.A.; Ali, I.M.; Elleithy, R.M. Covering materials incorporating radiation-preventing techniques to meet greenhouse cooling challenge in arid regions: A review. Sci. World J. TSWJ 2012. [CrossRef] [PubMed]

2. Abdel-Ghany, A.M.; Picuno, P.; Al-Helal, I.M.; Alsadon, A.A.; Ibrahim, A.; Shady, M.R. Radiometric characterization, solar and thermal radiation in a greenhouse as affected by shading configuration in an arid climate. Energies 2015, 8, 13928-13937. [CrossRef]

3. Hesham, A.A.; Al-Faraj, A.A.; Abdel-Ghany, A.M. Shading greenhouses to improve the microclimate, energy and water saving in hot regions: A review. Sci. Hortic. 2016, 201, 36-45.

4. Castellano, S.; Scarascia, G.M.; Russo, G.; Briassoulis, D.; Mistriotis, A.; Hemming, S. Plastic nets in agriculture: A general review of types and applications. Appl. Eng. Agric. 2008, 24, 799-808. [CrossRef]

5. Abdel-Ghany, A.M.; Picuno, P.; Al-Helal, I.M.; Shady, M.R. Modified plastic net-houses as alternative agricultural structures for saving energy and water in hot and sunny regions. Renew. Energy 2016, 93, 332-339. [CrossRef] 
6. Kittas, E.; Bartzanas, T.; Savvas, D.; Katsoulas, N. Effect ofshading on greenhouse energy balance and crop transpiration. Acta Hortic. 2012, 927, 689-694. [CrossRef]

7. Katunsky, D.; Lopusniak, M. Impact of shading structure on energy demand and on risk of summer overheating in a low energy building. Energy Procedia 2012, 14, 1311-1316. [CrossRef]

8. Ashour, R.M.; Muhaisen, A.S.; Ammar, S. Net Zero energy retrofit shading strategies of buildings in Gaza, case study: Multi-storey residential buildings. In Proceedings of the 7th IEEE Palestinian International Conference on Electrical and Computer Engineering (PIECE), Gaza, Palestine, 26-27 March 2019.

9. Baille, A.; Kittas, C.; Katsoulas, N. Influence of whitening on greenhouse microclimate and crop energy portioning. Agric. Forest Meteorol. 2001, 107, 293-306. [CrossRef]

10. Mashonjowa, E.; Ronsse, F.; Mhizha, T.; Milford, J.R.; Lemeur, R.; Pieters, J.G. The effects of whitening and dust accumulation on the microclimate and canopy behavior of rose plants (Rosa hybrida) in a greenhouse in Zimbabwe. Sol. Energy 2010, 84, 10-23. [CrossRef]

11. Al-Helal, I.M.; Abdel-Ghany, A.M. Response of shading nets to global and diffuse PAR transfer: Optical properties and evaluation. NJAS-Wagening. J. Life Sci. 2010, 57, 125-132. [CrossRef]

12. Abreu, P.E.; Meneses, J.F. Influence of soil covering, plastic ageing and roof whitening on climate and tomato crop response in an unheated plastic Mediterranean greenhouse. Acta Hortic. 2000, 534, 343-350. [CrossRef]

13. Chauhan, P.M.; Kim, W.S.; Lieth, J.H. Combined effect of whitening and ventilation methods on microclimate and transpiration in rose greenhouse. In Proceedings of the International Conference on Thermal Energy Storage Technologies, Indore, India, 21-24 March 2003.

14. Jimenez, S.; Plaza, B.M.; Perez, M.; Lao, M.T. Impact of whitewash coated polyethylene film cover on the greenhouse environment. J. Indian Agric. Res. 2010, 44, 131-135.

15. Gázquez, J.C.; López, J.C.; Pérez-Parra, J.J.; Baeza, E.J.; Lorenzo, P.; Caparros, I. Effects of three cooling systems on the microclimate of a greenhouse with a pepper crop in the Mediterranean area. Acta Hortic. 2012, 927, 739-746. [CrossRef]

16. Hatem, M.H.; El-Ebaby, F.G.; Badawy, E.M.; Emam, R.H. Effect of external shading for greenhouse on growth and quality of some ornamental plants. Misr. J. Agric. Eng. 2007, 24, 630-647.

17. Ghosal, M.K.; Tiwari, G.N.; Srivastava, N.S.L. Modeling and experimental validation of a greenhouse with evaporative cooling by moving water film over external shade cloth. Energy Build. 2003, 35, 843-850. [CrossRef]

18. Medrano, E.; Lorenzo, P.; Sa'nchez-Guerrero, M.C.; Garcı'a, M.L.; Caparro's, I.; Gime'nez, M. Influence of an external greenhouse mobile shading on tomato transpiration. Acta Hortic. 2004, 659, 195-199. [CrossRef]

19. Chen, C.; Shen, T.; Weng, Y. Simple model to study the effect of temperature on the greenhouse with shading nets. J. Afr. Biotech. 2011, 10, 5001-5014.

20. Holcman, E.; Sentelhas, P.C. Microclimate under different shading screens in greenhouses cultivated with bromeliads. Engenharia Agrícola e Ambiental 2012, 16, 858-863. [CrossRef]

21. Garcia, M.L.; Medrano, E.; Sanchez-Guerrero, M.C.; Lorenzo, P. Climatic effects of two cooling systems in greenhouses in the Mediterranean area: External mobile shading and fog system. Biosyst. Eng. 2011, 108, 133-143. [CrossRef]

22. Al-Helal, I.M.; Abdel-Ghany, A.M. Measuring and evaluating solar radiative properties of plastic shading nets. Sol. Energy Mater. Sol. Cells 2011, 95, 677-683. [CrossRef]

23. Duffie, J.A.; Beckman, W.A. Solar Engineering of Thermal Processes; John Wiley \& Sons: New York, NY, USA, 1991.

24. Al-Mahdouri, A.; Baneshi, M.; Gonome, H.; Okajima, J.; Maruyama, S. Evaluation of optical properties and thermal performances of different greenhouse covering materials. Sol. Energy 2013, 96, 21-32. [CrossRef]

25. Abdel-Ghany, A.M.; Kozai, T.; Chun, C. Evaluation of selected greenhouse covers for use in regions with a hot climate. Jpn. J. of Trop. Agric. 2001, 45, 242-250.

26. Abdel-Ghany, A.M. Solar energy conversions in the greenhouses. Sustain. Cities Soc. 2011, 1, $219-226$. [CrossRef]

(C) 2019 by the authors. Licensee MDPI, Basel, Switzerland. This article is an open access article distributed under the terms and conditions of the Creative Commons Attribution (CC BY) license (http://creativecommons.org/licenses/by/4.0/). 